\title{
John Crowe Ransom's \\ "Vaunting Oak": an Answer to
}

"The Equilibrists"

By Orm Overland,

Dept. of English, Univ. of Bergen, Norway

In many of his poems John Crowe Ransom has juxtaposed two contrasting human responses to life frequently referred to by the conventional symbols of "head" and "heart." The head is intellectual, and cold and bitter in its knowledge; the heart is warm but all to short sighted, and its visions turn out to be illusions. Man's dilemma is that without a synthesis of these two responses he is essentially a grotesque. Caught in the struggle between them he seems fated to remain in a deathlike equilibrium between Heaven and Hell like "The Equilibrists."

In "Eclogue" there seems to be no possible fusion between Jane Sneed's beautiful dream world and the bitter knowledge of John Black. Jane Sneed can picture a world where lovers unafraid

keep the whole night through,

Till the sun of a sudden glowing through the bushes

They wake and laugh, their eyes again are blue,

They run to the fields, and beautiful the thrushes,

Fabulous the dew.

JOHN BLACK'S THE LAST SAY THEN: O innocent dove,

This is a dream. We lovers mournfully

Exchange our bleak despairs. We are one part love

And nine parts bitter thought. As well might be

Beneath ground as above. 
"Vaunting Oak" presents a similar pair of seemingly irreconcilable human responses to life. But contrary to poems like "Spectral Lovers," "Eclogue" or "The Equilibrists," this poem does not end on a note of despair. In the doomed oak Ransom has presented an image powerful enough to set off the insufficiency of either incomplete response to the totality which is life. "Vaunting Oak" therefore deserves far more attention as a central piece in Ransom's oeuvre than his critics have been willing to concede. Indeed, apart from passing comments by Cleanth Brooks and F.O. Matthiessen and the deprecatory criticism of Thornton H. Parsons, "Vaunting Oak" has hardly attracted any critical attention. ${ }^{1}$ Nevertheless, it is precisely because of its success as a poem that "Vaunting Oak" must be regarded as central also when it comes to a consideration of Ransom's themes.

Cleanth Brooks has commented on the poem's archaic and latinized diction which along with "a rather formal patterning of sentence structure" serves "to universalize the experience" it relates by taking it "out of a merely personal context." One may add that the rigid pattern of terza rima works in the same direction. This may, as Brooks observes, also be taken as "a kind of parody of the grand manner," but I am not prepared to follow Brooks when he claims that in the two concluding stanzas "the tone of the poem modulates into a deeper and more serious note in which the grand manner, earlier parodied, is reasserted this time with full seriousness...." On the contrary, the persistently ironic tone serves to define the point of view of the narrator-persona to the very end.

In the first three stanzas of the poem the great oak alone dominates the scene. The expressed admiration for this "tower unleaning" is in part undercut by the irony implied in the pompous and mannered diction of the narrator-persona, Nevertheless, there is admission of a certain greatness in the realization that although the oak may eventually be broken down, it will only be "If Heaven assault him with full wind and sleet." Strong men fall before lesser assaults than this and when the tree goes, it will be with a no in thunder: "And what uproar tall trees concumbent make!" The oalr rears in naked defiance "against the cold skies eruptive" and his more than

${ }^{1}$ Brooks, "The Doric Delicacy," and Matthiessen, "Primarily Language," The Sewanee Review, LVI (1948); Parsons, John Crowe Ransom (New York, 1969). 
hundred years are set off against "his temporal twigs" and "the frail leaves of a season."

Upon this scene enter two lovers. The girl is given in her essence, "a certain heart, too young." The concreteness of the synecdoche contrasts with the abstract image of her lover, "an unbeliever of bitter blood." The reader of Ransom's poetry is thus immediately warned that here, too, we have the familiar dichotomy of heart and head. Indeed, there is even the suggestion that the two lovers are merely images of these two aspects of the poet's person. Other implications of the phrase "mortally linked" are, however, more immediate. In its echoing of the church's marriage ritual it suggests a certain permanence to the lovers' union; but in recalling the image of the "temporal twigs... unsure of seat" the opposite suggestion of frailty and impermanence is equally present.

Being "too young" herself to have had much experience the girl looks to the oak "as an eminent witness of life." In his apparent permanence she sees a reassurance of a faith which the more ephemeral images of summer had threatened:

"Be the great oak for its long winterings

Our love's symbol, better than the summer's brood."

To one "wrapped in a phantasy of good" and not sufficiently "versed in country things" (to speak with Robert Frost) it would almost seem that the "venerable oak" responded to the girl's exultant observation when he

delivered of his pangs,

Put forth profuse his green banners of peace

And testified to her with innumerable tongues.

The girl, however, is not satisfied with accepting the oak as symbol where he stands alone on his hill. She must take her lover with her "up to the steep place / Where the oak vaunted." It is as if her own faith is not strong enough and she feels the need to convince herself as well as her lover, the bitter "unbeliever," of the truth in the symbol she has chosen. Indeed, her love seems to need to leari on the oak, himself "a tower unleaning."

Up to this point the poet has more or less dissociated himself from the bitter unbeliever through the use of the third person. Now the 
reader is made to realize that the point of view is not external: the use of the pronoun "me" joins the lover and the narrator. By delaying this identification, however, Ransom has succeeded in suggesting a certain distance between the two. This distance is part of the strategy that enables the poet to direct his irony at both of the two characters in the poem. Whereas Ransom is taken to task by Parsons for the "pedantic," "bombastic," "Latinate," "florid," and inflated language of the poem, a. more sympathetically inclined reader of the poem may regard the mannered style as a characterization of the narrator-persona rather than of the poet himself. An apprecation of the significance and function of the style is thus essential to an understanding of the poem as a whole.

The girl, "who had been instructed of much mortality" (no doubt by her bitter lover), knows better than to look for affirmation to "the summer's brood," the "quick populace" of flowers soon to wither and die. But the oak seems to rise "above the little and their dusty tombs" and beside him she is reassured enough to brag (as the oak himself has seemed to do): "Established, you see him there! forever." Throughout the poem the oak has been seen as opposed to the "temporal" and the mortal, the "frail leaves of a season" and the "quick" flowers, alive but ephemeral. Now the knock of the "sorrowing lover" draws forth a hollow tone "like a funeral" from the tree. With the word funeral we suddenly realize that the vaunting oak himself embodies the frailty and mortality against which he has been placed as a symbol of hope, and that this is what the series of images of death have been leading up to. With this reversal the symbol of hope becomes a symbol of despair more bleak than that which could be brought out by the "quick populace" whose ephemeral quality is readily granted by anyone with the least instruction in mortality.

Yet, as the sorrowing lover is forced to admit, "the old gentleman holds gallantly" in spite of his inevitable fate. His greatness and the strength of the powers needed successfully to assault him raise his fall up to the level of tragedy. It is his naked defiance of death in the face of "the cold skies," that makes his "dolorous cry" outsound the buzzing of ephemeral insects and the cowardice of creatures who flee rather than take on the challenge of winter. It also outsounds "the tears of a girl remembering her dread." 
It has already been noted that the girl seems insecure in her faith and feels the need to touch the oak, to assure both herself and her lover of its reality and through it of the reality of their love. Her dread, then, is not a response to the funeral tone drawn forth by the lover's knock; the dolorous cry has merely served as a reminder of a dread she has had all along. The cry of the tree outsounds her tears as the tragedy of a hero alone defying the cold heavens is greater than that of a doubting attendant or follower.

Does the poet, then, finally identify himself with the cynical and bitter lover and say that such impulses from the vernal wood on closer inspection turn out to be horrors in disguise? It has already been suggested that the distance established between the poet and his narrator-persona, in part through the ironic tone of the poem, in part through the initial use of the third person, enables the poet to have his poem say something more than the mere thesis and antithesis of either lover. Although one is forced to realize that all life is mortal, one may still be able to admit that a certain greatness is involved in the oak's act of defiance of this fact. It would seem that the girl has chosen a good symbol for love even though her own love apparently is not strong enough to own up to it.

In "Vaunting Oak" the bitter lover does not have the last say as did John Black in "Eclogue." The heart alone may be too weak, the head too cold. The symbol of the towering oak, though it too is doomed in the sense that all mortal life Is doomed, finally stands stronger than both the girl's "phantasy of good" and her lover's "bitter blood." 